\title{
REKONTRUKSI LAPORAN KEUANGAN DISTRIBUTOR MOLRENG JEMBER BERDASARKAN SAK EMKM
}

\author{
Almira Ayu Octavia ${ }^{1}$ \\ Email:ayu.almira15@gmail.com \\ Rochman Effendi ${ }^{2}$ \\ Whedy Prasetyo ${ }^{3}$
}

\begin{abstract}
This study discusses the suitability and financial reporting of Molreng Jember Distributors based on SAK EMKM. The method used by researchers is a qualitative method. This research is a case study with the object of research on the financial statements of Molreng Jember Distributors who have not yet applied the SAK EMKM-based financial reporting. Data retrieval is done by interview and documentation. This study shows that Molreng Jember Distributors only make simple records, considering the lack of understanding in making financial reports. Molreng Jember Distributors only record income and borrowing in order to obtain the final result in the form of profit. Financial reports for Molreng Jember Distributors can be accessed by the owner to find out how the business actually is so that they can determine the selling price for the following year.
\end{abstract}

Keywords: Financial statements, UMKM, SAK EMKM

\section{PENDAHULUAN}

Rekontruksi merupakan penyusunan atau penggambaran kembali. Konsep penyusunan kembali oleh peneliti diterapkan dalam penyajian laporan keuangan pada Usaha Mikro, Kecil, dan Menengah (UMKM). UMKM yang diteliti mempunyai catatan harian untuk transaksinya, dari catatan harian tersebut peneliti akan menyesuaikan dan menyusun kembali sesuai pedoman yang ada di Indonesia yaitu Standar Akuntansi Keuangan Entitas Mikro, Kecil, dan Menengah (SAK EMKM). Pencatatan yang dilakukan kepada UMKM mempunyai beberapa manfaat sepertininformasi transaksi dengan bahasa yang dapat dipahami dan beberapa terdapat dokumen pendukung setiap transaksi. Berdasarkan hal ini dapat disimpulkan jika UMKM dapat memanfaatkan catatan tersebut untuk kegiatan transaksi yang

\footnotetext{
${ }^{1}$ Corresponding author: Jurusan Akuntansi, Fakultas Ekonomi dan Bisnis, Universitas Jember, Jalan Kalimantan No. 37, Kampus Tegalboto, Kecamatan Sumbersari, Jember, 68121, Jawa Timur, Indonesia.

2,3 Jurusan Akuntansi, Fakultas Ekonomi dan Bisnis, Universitas Jember, Jalan Kalimantan No. 37, Kampus Tegalboto, Kecamatan Sumbersari, Jember, 68121, Jawa Timur, Indonesia.
} 
dirasa penting untuk aktivitas usahanya dan dapat memudahkan pengecekan atau meneliti transaksi yang telah terjadi pada periode tertentu. Penulisan transaksi sesuai tanggal dalam catatan dapat meminimalkan kecurangan seperti rekayasa pencatatan. Catatan seperti ini lebih ringkas daripada hanya bukti transaksi karena lebih banyak menampung transaksi dan lebih tahan lama (Warsono 2010).

Usaha Mikro, Kecil, dan Menengah (UMKM) merupakan sektor penting dalam perekonomian, khususnya Indonesia. Di kasus ini, terbukti dalam masa krisis terdapat banyak usaha besar atau nasional-mutinasional dililit hutang. Selain itu, terkadang banyak UMKM melakukan ekspor yang malah meraup profit yang besar. Dikarenakan investasi dan modal, banyak usaha yang menggunakan berbagai cara untuk mengatur strateginya.

Sudaryanto et al. (2012) menyatakan hampir semua UMKM di Indonesia merupakan usaha mikro di sektor informal dan bahan baku yang digunakan biasanya bahan baku lokal yang dapat ditemukan dalam pasar lokal. Oleh karena itu, UMKM lebih tahan terhadap gejala ekonomi seperti krisis global. UMKM perlu memiliki skill dalam menghadapi persaingan perdagangan dunia agar tetap mampu bertahan demi perekonomian Indonesia yang stabil. Tidak dipungkiri bahwa sumber daya manusia juga memiliki andil dalam kemampuan UMKM di dalam persaingan dagang. Permasalahan yang sering dihadapi oleh UMKM berkaitan dengan prospek usaha yang kurang jelas serta visi dan misi, serta perencanaan yang belum matang. Hal ini terjadi karena UMKM biasanya bersifat menaikan pendapatan, maksudnya UMKM merupakan usaha keluarga, teknologi yang digunakan masih sederhana, akses permodalan sangat minim, dan tidak ada pemisahan modal usaha dan kebutuhan-kebutuhan pribadi. Menurut Alhusain dalam Warsono (2010) sebagian besar pelaku bisnis atau UMKM beranggapan keberhasilan usaha mereka adalah kecukupan dalam kebutuhan kesehariannya. Seringkali UMKM dalam melakukan aktivitas bisnisnya menggunakan modal pribadi, selain itu perputaran uang atas hasil yang didapat seperti laba, sehingga usaha yang dilakukan dan dikembangkan hanya sebatas modal yang dimiliki.

Potensi terbesar dalam UMKM biasanya terkendala karena masalah modal untuk pengembangan usahanya. Sehingga, pemerintah mengadakan program untuk pendanaan UMKM yang disebut Kredit Usaha Rakyat (KUR) ditahun 2009 yang menargetkan sekitar dua puluh triliun. Tujuannya adalah supaya KUR menjadi solusi pembiayaan modal yang efektif untuk UMKM, karena banyak UMKM yang terkendala akses terhadap perbankan untuk mendapatkan pembiayaan. Namun, realiasi KUR tersebut jauh dari target yakni hanya sebesar Rp 14,8 triliun (Osa dalam Rudiantoro dan Siregar (2012). UMKM yang terkendala akses terhadap perbankan untuk mendapatkan pembiayaan pengembangan usaha biasanya karena pelaku UMKM tidak melakukan pencatatan dan penyusunan laporan keuangan sesuai dengan kegiatan usaha dan posisi keuangan perusahaan (Moleong, 2017). UMKM hanya mencatat uang yang diterima dan dikeluarkan, barang dibeli dan dijual, serta piutanggatau utang. Hal itu wajar, karena penyusunan sebuah laporan keuangan merupakan tahap awal dari akuntansi yang dapat menghasilkan informasi yang berkaitan dengan penyusunan perencanaan, pengendalian usaha, serta pengambilan keputusan keuangan pada UMKM (Kristanto, 2011).

Penyusunan laporan keuangan merupakan bukti terlaksananya penerapan prinsip akuntansi yang tepat pada UMKM. Oleh karena itu, penerapan akuntansi serta penyusunan laporan keuangan harus berpedoman pada standar keuangan 
sehingga laporan keuangan yang disajikan dalam UMKM memiliki kepercayaan dari semua pihak. Standar Akuntansi untuk penyusunan laporan keuangan yang dapat digunakan untuk UMKM di Indonesia adalah Standar Akuntansi Keuangan Entitas Mikro, Kecil, dan Menengah (SAK EMKM).

SAK EMKM digunakan oleh akuntantabilitas publik yang memenuhi definisi UMKM. SAK EMKM disusun untuk memenuhi kebutuhan pelaporan keuangan entitas mikro, kecil, dan menengah. SAK EMKM ditujukan untuk entitas yang tidakkatau belum mampu memenuhi persyaratan akuntansi yang diatur dalam SAK ETAP. SAK EMKM bisaadibilang standar keuangan yang sederhana, namun output dari laporan keuangannya adalah informasi yang handal dalam penyajian laporan keuangan.

Dari permasalahan diatas, penulis tertarik untuk melakukan penelitian mengenai penyusunan laporan keuangan berdasarkan SAK EMKM. Penelitian ini dilakukan pada distributor makanan yaitu Molreng Jember. Usaha Mikro, Kecil, dan Menengah ini adalah salah satu usaha yang bergerak pada usaha dagang. UMKM hanya menggunakan catatan sederhana karena tidak mengetahui bagaimana cara membuat laporan keuangan. Melihat pentingnya suatu pembukuan atau catatan akuntansi untuk pelaporan keuanganbbagi distributor, maka dari itu penulis akannmerekonstruksi laporan keuangan yang dibuat distributor ke SAK EMKM.

\section{METODE PENELITIAN}

\subsection{Jenis Penelitian}

Penelitian kualitatif dimaksudkan untuk menggambarkan sebuah kegiatan berdasarkan yang terjadi sebagaiikajian untuk mengetahui letak kelemahan supaya dapat dilakukan perbaikan. Moleong (2017) menyatakan jika kualitatif merupakan penelitian yang dimaksudkan untuk mengetahui fenomena apa saja yang dialami subjek penelitian misalnya, persepsi, motivasi, tindakan, perilaku, dengan cara deskripsi bentuk kata dan bahasa, pada konteks khusus dengan memanfaatkan beragam metode ilmiah.

Metode yang digunakan adalah deskriptif, yaitu metode untuk mencari unsur, ciri, dan sifat. Metode dimulai dari mengumpulkan, menganalisis dan menginterprestasikan data. Dalam pelaksanaan yang dilakukan dengan teknik survei, analisis dokumenter, studi kasus, studi tentang waktu \& gerak, analisis tingkah laku, dan studi komparatif. (Suryana, 2010). Fokus penelitian kualitatif digunakan untuk melihat kondisi suatu obyek atau sebagai penelitian yang menggunakan instrumen sehingga hasil yang didapat langsung dapat dibandingkan tolak ukur untuk mendapatkan kesimpulan.

\subsection{Tempat dan Waktu Penelitian}

Penelitian di Jalan Mastrip no 67B Kecamatan Sumbersari Kabupaten Jember. Pemilihan lokasi penelitian ini dipilih karena distributor melakukan usaha ditempat tinggalnya. Selain itu, distributor memberi informasi dan data digunakan untuk penelitian. Dimulai tanggal 1 Desember 2018 sampai dengan berakhir pengumpulan skripsi. Dalam jangka waktu tersebut, penelitian memberikan gambaran yang cukup mengenai laporan keuangan pada distributor Molreng Jember untuk kemudian di rekonstruksi sesuai dengan SAK EMKM. 


\subsection{Sumber dan Jenis Data}

Lofland dan Lofland dalam Moleong (2017) menyatakan jika data utama pada penelitian kualitatif yaitu tindakan serta kata. Berkaitan dengan hal tersebut dibagian ini jenis data dibagi dalam tindakan dan kata, sumber tertulis, foto, dan statistik. Pada penelitian ini mengambil sumber dari tindakan dan kata. Maksud dari tindakan dan kata adalah data utama dicatat tertulis atau melalui perekaman suara, dan pengambilan foto. Sedangkan sumber yanggtertulis adalah sumber data tambahannyang dibagi atas sumber buku pedoman yaitu SAK EMKM, serta dokumenp pribadi yaitu berupa catatan harian yang dilakukan distributor molreng Jember.

\subsection{Teknik Pengumpulan Data}

Teknik pengumpulan data adalah teknik penting dalam penelitian sebab tujuan utamanya yaitu mendapatkan data (Sugiyono 2010). Teknik pengumpulan data yang digunakan oleh peneliti yaitu:

\section{Wawancara}

Menurut Moleong (2017) wawancara adalah percakapan yang dilakukan dengan tujuan tertentu. Dilakukan dengan dua pihak, yaitu pewawancara dan terwawancara. Pada penelitian ini, pendekatan menggunakan petunjuk umum wawancara. Maksud dari petunjuk umum wawancara berisi secara umum bagaimana proses dan isi dari wawancara. Proses pewawancara serta pertanyaan yang diajukan harus disesuaikan dengan keadaan pada konteks wawancara yang sebenarnya. Peneliti mewawancarai pemilik Distributor Molreng Jember yang bernama Naimatul Laili.

2. Dokumentasi.

Dokumentasi adalah catatan peristiwa yang telah berlalu (Sugiyono 2010). Peneliti pada penelitian ini menggunakan dokumen pribadi. Menurut Moleong (2017), bahwa dokumen pribadi merupakan karangan seseorang yang tertulis berupa tindakan, pengalaman, serta kepercayaannya. Terdapat tiga macam dokumen, seperti surat pribadi, autobiografi, dan buku harian. Diantara ketiga itu yang dipakai penelitian bukan peneliti minta untuk disusun, melainkan sudah ada. Sedangkan yang digunakan pada penelitian ini yaitu bukuuharian. Dokumen berupa catatan keuangan. Dokumentasi yang dilakukan yaitu foto.

\subsection{Teknik Analisis Data}

Proses pencarian serta penyusunan secara sistematis dari data yang diperoleh dari lapangan, nantinya dapat mudah dipahami dan diinformasikan ke orang lain dinamakan analisis data. Penelitian kualitatif disini pada pengolahan data laporan keuangan Distributor Molreng Jember sehingga data dapat menjadi sebuah laporan keuangan yang bermanfaat pada UMKM, SAK EMKM pada penelitian ini digunakan sebagai alat analisis untuk peneliti.

SAK EMKM dijadikan standar akuntansi keuangan untuk digunakan dalam penyusunan laporan keuangan pada usaha kecil menengah yang kebanyakan belum menerapkan standar dalam pencatatan keuangan. Diawali dengan mempelajari SAK EMKM lalu dianalisis supaya mengetahui standar pelaporan keuangan mana yang memudahkan distributor untuk diterapkan, selanjutnya melakukan perbandingan 
pada unsur laporan keuangan sesuai SAK EMKM. Langkah terakhir yaitu menerapkan SAK EMKM sebagai pedoman untuk menyusun laporan keuangan.

\section{HASIL DAN PEMBAHASAN}

\subsection{Gambaran Umum Objek Penelitian}

Latar belakang dibentuknya bisnis ini adalah keadaan ekonomi sebagai mahasiswa. Pelaku UMKM, distributor Molreng Jember, awalnya melakukan bisnis pada saat menjadi mahasiswa bidikmisi salah satu universitas di Jember. Menjadi salah satu mahasiswa yang mengandalkan bidikmisi, mengharuskannya mencari tambahan biaya untuk kehidupan di Jember. Distributor berinisiatif untuk menjual makanan ringan yang sudah diketahui sejak SMK. Distributor berfikir bahwa ada peluang untuk memasarkan produk tersebut di Jember, karena di Jember belum ada makanan ringan kemasan yang terbuat dari cimol. Molreng singkatan dari "Cimol Digoreng" adalah salah satu produk yang dihasilkan oleh CV. TKT Bana Food. Awalnya, distributor mengambil produk langsung dari pabrik lalu dipasarkan di Jember secara berulang. Dari kejadian tersebut pihak perusahaan menawarkan kerjasama, yaitu menjadi seorang distributor wilayah bagian Jember. Sistem penjualan yang diterapkan oleh perusahaan adalah menempatkan satu orang di satu wilayah untuk pemasaran dan pengembangan produk dengan menyetorkan modal awal sebagai syarat.

Dengan menyetorkan modal awal sebesar lima juta rupiah pada perusahaan tersebut. Pada bulan Desember 2014, distributor resmi memasarkan produk Molreng di Jember selagi ia menjadi mahasiswa aktif. Menjadi seorang distributor resmi perusahaan, maka pasar yang dituju sudah ada. Pelanggan online yang tertarik dan ingin memesan produk Molreng pasti akan menghubungi perusahaan, lalu perusahaan akan memberikan kontak distributor resmi di wilayah masing-masing. Sebenarnya CV. TKT Bana Food mempunyai beberapa produk yang unggul yaitu Basreng (Bakso Goreng), Molreng (CImol Goreng), Boncu (Abon Cabe Unik) dengan brand SEUHALATALATA. Fokus distributor hanya kepada penjualan produk Molreng karena produk tersebut paling diminati oleh masyarakat jember. Dari segi rasa yang ditawarkan dan segi harga yang bisa dijangkau untuk anak sekolah hingga mahasiswa.

Distributor Molreng wilayah Jember tidak hanya memasarkan produk di kota Jember, namun juga di kota lain seperti Situbondo, Bondowoso, Banyuwangi, serta Lumajang. Dengan rata-rata peminatnya remaja. Di kota yang disebutkan belum ada distributor resmi perusahaan, jadi distributor wilayah Jember dapat mendistribusikan produk pada kota tersebut. Pemesanan barang dagang atau stok produk oleh distributor dimulai dari pemesanan ke perusahaan pada bulan sebelumnya, sehingga bulan berikutnya distributor hanya membayar pembelian tersebut. Penjualan yang dilakukan oleh distributor yaitu memanfaatkan reseller/agen. Sistem pembayaran yang digunakan oleh agen/reseller kepada distributor adalah tunai dan kredit. Produk yang tersedia di distributor biasanya diantar ke tempat reseller/agen jika berada di daerah kampus. Jika ada yang berada di luar kota akan dilakukan pengiriman dengan beban ongkos kirim yang ditanggung oleh pembeli. 


\subsection{SAK EMKM pada UMKM}

Laporan keuangan adalah suatu yang penting, apalagi untuk suatu UMKM. Penyusunan laporan keuangan pada UMKM dapat didasarkan pada standar akuntansi keuangan. Ikatan Akuntan Indonesia (IAI) mengeluarkan standar akuntansi yang dapat digunakan untuk UMKM, yakni SAK EMKM. Perlu diketahui, SAK-ETAP berguna untuk entitas tanpa akuntanbilitas publik yang signifikan, namun menerbitkan laporan keuangan untuk tujuan umum bagi pengguna eksternal. Sedangkan, SAK-EMKM berguna sebagai pemenuhan kebutuhan pelaporan keuangan entitas mikro, kecil, dan menengah. Sehingga adanya laporan UMKM yang sudah terstandarisasi berdasarkan SAK EMKM, dapat menjadi solusi untuk kendala UMKM serta jawaban untuk kegelisahan pemerintah pada kelangsungan hidup pelaku bisnis teratasi, sebab itu UMKM memiliki laporan keuangan supaya mandiri dan maju.

\subsection{Laporan Keuangan UMKM Berdasarkan SAK EMKM}

Berdasarkan fokus obyek penelitian yaitu Distributor Molreng Jember. Objek penelitian melakukan pencatatan akun-akun aktivitas usahanya secara tertib dan dapat dibuktikan tanggung jawabnya sebagai langkah menyusun laporan keuangan didasarkan dengan aturan yang terdapat pada SAK-EMKM. Seluruh aktivitas usaha yang terdapat di UMKM dianalisis lalu diproses supaya didapatkan lap. Keuangan sesuai SAK EMKM. Analisis pada akuntansi sepenuhnya didasarkan pada persamaan akuntansi. Persamaan dasar akuntansi adalah persamaan yang secara global dan terpadu menggambarkan sebuah hubungan yang ada di perusahaan seperti antara aktiva dan simbernya. Bentuk persamaan akuntansi adalah sebagai berikut

$$
\begin{aligned}
& \text { AKTIVA }=\text { PASSIVA } \\
& \text { HARTA }=\text { UTANG }+ \text { MODAL } \\
& \text { HARTA }=\text { KEWAJIBAN }+ \text { EKUITAS }
\end{aligned}
$$

Rumusan persamaan akuntansi diatas sifatnya baku, sama halnya dengan yang dikatakan Hery (2013) yaitu

\section{ASET $=$ LIABILITAS + EKUITAS}

Persamaan diatas maksudnya adalah dimana liabilitas atau yang biasa disebut dengan hutang harus ditempatkan lebih dulu sebelum ekuitas, persamaan tersebut memberikan makna bahwa kreditur memiliki hak pertama atas kekayaan perusahaan, setelah itu para pemegang saham.

\subsection{ASET}

Menurut Naimatul Laili, selaku owner dari distributor molreng Jember bahwa aset adalah barang atau bangunan yang mempunyai nilai harga. Pernyataan tersebut menunjukkan bahwa umkm mempunyai konsep tentang aset berupa barang atau bangunan. Hal ini sejalan dengan SAK EMKM (2018), bahwa sumber daya yang entitas miliki disebabkan oleh peristiwa masa lalu dan diharapkan memberi manfaat ekonomik masa depan entitas. Namun, di dalam hasil pencatatan keuangannya ada ketidaksinkronan terutama definisi tentang kas. Owner, Naimatul Laili, tidak menyadari bahwa uang yang diterima ketika aktivitas usaha sebagai kas. Maka dari 
itu saya menambahkan akun yang dinamakan kas. Hal ini sejalan dengan pernyataan Naimatul laili bahwa distributor tidak mengetahui akun yang didalam laporan keuangan jika menerima uang hasil usahanya. Pernyataan tersebut merupakan konsep akun kas sebagaimana definisi dari Warsono (2010) bahwa kas adalah sebuah aktiva dapat digunakan segera untuk mendanai kegiatan UMKM.

Naimatul Lailatul menegaskan bahwa pada bulan Desember terdapat reseller yang belum membayar. Hal ini menunjukkan bahwa umkm juga melakukan penjualan kredit, sehingga tidak menyadari bahwa memiliki pendapatan yang masih belum diterima dari aktivitas usaha. Oleh dari itu, saya menambahkan akun yang dinamakan piutang. Sejalan dengan pendapat Hery (2013), bahwa piutang sendiri dapat dikatakan aktiva karena nantinya dapat (di-convert) dari piutang dijadikan kas, karena hasil oleh penagihan barang yang dijual.

Menurut Owner, Naimatul Laili, menyatakan bahwa jika akan memesan barang ke pemasok maka akan dilakukan pengecekan kembali barang yang siap dijual. Berdasarkan pernyataan tersebut diketahui bahwa umkm sudah melakukan pencatatan barang yang tersisa dari periode sebelumnya sebagai persediaan. Sejalan dengan pendapat Hery (2013), bahwa persediaan dikatakan aktiva disebabkan nantinya dapat dijual pada pelanggan untuk dapat piutang/kas pada akhirnya. Dalam SAK EMKM (2018), dijelaskan bahwa persediaan merupakan aktiva yang dijual pada aktivitas biasa, diproses produksi untuk dijual, atau bentuk bahan/ perlengkapan dalam proses produksi/pemberian jasa.

Owner, menyatakan jika mempunya aset yang berupa sepeda motorr yang biasanya digunakan mengantarkan barang dagang ke reseller. Hal tersebut menyatakan bahwa perusahaan mempunyai aktiva tetap yang berupa kendaraan untuk operasional usahanya. Sejalan dengan SAK EMKM (2018) bahwa aset tetap merupakan aktiva entitas yang digunakan pada kegiatan normal usaha yang diharapkan untuk digunakan entitas lebih dari satu periode. Pada pencatatan penyesuai menurut PABU menurut Warsono (2010) mengakui adanya biaya penyusutan, yaitu yang dialami sebagai penurunan nilai karena dipakai untuk mendapatkan pendapatan oleh karena itu, penurunan nilai aset tetap wajib dibandingkan pada pendapatan selama periode. Sedangkan, UMKM tidak mengerti bagaimana cara menghitung penyusutan kendaraan yang dimiliki hingga umur ekonomisnya habis. Oleh karena itu, peneliti menambahkan akun yang dinamakan akumulasi penyusutan kendaraan.

\subsection{LIABILITAS}

Menurut Hery (2013) liabilitas merupakan kewajiban perusahaan kepada kreditur (supplier, banker) dan pihak lainnya (karyawan, pemerintah). Terdapat empat macam utang, yaitu utang usaha, pinjaman bank, utang gaji, dan utang pajak penghasilan. Owner, Naimatul Laili, menyatakan bahwa masalah hutang hanya menggunakan modalnya sendiri dari perputaran uang usaha. Berdasarkan pernyataan diatas, maka untuk akun liabilitas dari umkm tidak ada, pengisian dalam laporan keuangan harus disamakan dengan 0 (nol).

\subsection{EKUITAS}

Dalam SAK EMKM (2018), ekuitas adalah hak residual atas aset entitas setelah dikurangi seluruh liabilitasnya. Dalam entitas ini diketahui bahwa modal yang 
digunakan adalah laba bersih pemilik dikurangi prive pemilik. Menurut Warsono (2010), bahwa modal dicontohkan setoran modal dari pemilik bernama Ibu Amalia, hal ini sejalan dengan pernyataan owner, Naimatul Laili, bahwa modal adalah dana awal yang digunakan untuk mulai melakukan suatu bisnis. Dari pernyataan diatas, usaha distributor ini memiliki yang dinamakan akun modal pemilik.

Owner, Naimatul Laili, memang menggunakan uang usaha untuk membiayai kehidupannya selama ini. Sehingga distributor melakukan pencatatan pengambilan uang. Berdasarkan pernyataan tersebut bahwa pemilik usaha melakukan pengambilan pribadi atau prive. Prive termasuk elemen pengembalian ekuitas karena khusus untuk transaksi yang menyebabkan perpindahan ekuitas ke pemilik (Warsono, 2010). Dari pernyataan tersebut, distributor ini memiliki akun yang dinamakan akun prive.

Dari pernyataan - pernyataan diatas dapat dijadikan pedoman untuk menyusun laporan keuangan sesuai SAK EMKM sebagai berikut:

1. Aset

a. Kas

b. Piutang

c. Persediaan

d. Kendaraan

2. Liabilitas

e. Ak Peny Kendaraan

3. Ekuitas
a. Modal Pemilik
b. Prive

Menurut SAK EMKM (2018), dalam entitas ini diketahui bahwa terdapat ekuitas dan Informasi kinerja entitas terdiri dari informasi mengenai penghasilan dan beban selama periode pelaporan, dan disajikan dalam laporan laba rugi.

\subsection{PENGHASILAN}

Penghasilan (Income) adalah kenaikan manfaat ekonomik selama periode pelaporan dalam bentuk arus kas masuk atau kenaikan asset, atau penurunan liabilitas yang mengakibatkan kenaikan ekuitas yang tidak berasal dari kontribusi penanam modal. Selain itu, Pandiagaan (2014) mengatakan bahwa pendapatan merupakan adanya arus kas masuk yang bisa menambah aset dan digunakan untuk mendanai operasional suatu entitas guna mencapai tujuannya. Entitas yang diteliti adalah perusahaan dagang. Oleh karena itu, distributor mempunyai akun yang dinamakan penjualan.

Naimatul Lailatul menyatakan jika tidak pernah menghitung harga pokok penjualan. Melihat hanya dii akhir periode dan mencocokkan dengan pencatatan. Hal ini menunjukkan bahwa umkm mencatat persediaan akhir dari satu periode untuk persediaan awal bagi periode selanjutnya. Distributor hanya menghitung sisa barang yang tersedia padahal seperti yang dinyatakan oleh Hery (2013) bahwa dalam perusahaan dagang, persediaan merupakan aset lancar, maka harga pokok penjualan dapat ditentukan dengan menggunakan rumus yaitu persediaan awal ditambah harga pokok pembelian dikurangi persediaan akhir. Oleh karena itu, peneliti membuatkan serta menambahkan akun harga pokok penjualan untuk mengetahui laba kotor perusahaan. 


\subsection{BEBAN}

Beban (expenses) adalah penurunan manfaat ekonomik selama periode pelaporan dalam bentuk arus kas keluar atau penurunan aset, atau kenaikan liabilitas yang mengakibatkan penurunan ekuitas yang tidak disebabkan oleh distribusi kepada penanam modal. Warsono (2010), bahwa beban penyusutan pengakuan biaya atas penurunan nilai dari aset tetap yang dapat disusutkan. Oleh karena itu, peneliti menambahkan akun bernama beban penyusutan kendaraan.

Naimatul Laili menyatakan bahwa beban yang dikeluarkan mulai dari beban angkut hingga pembelian plastik biayanya seratus ribu rupiah. Berdasarkan pernyataan tersebut berati umkm menulis beban. Jadi, distributor mempunyai akun yang bernama akun beban angkut pembelian. Dari pernyataan - pernyataan diatas dapat dijadikan pedoman untuk menyusun laporan keuangan sesuai SAK EMKM sebagai berikut:

1. Penjualan

2. Harga Pokok Penjualan

3. Beban

a. Beban penyusutan kendaraan

b. Beban Angkut Pembelian

\section{KESIMPULAN}

Berdasarkan hasil penelitian, penulis menarik kesimpulan bahwa perhitungan yang dilakukan oleh Distributor Molreng Jember belum disusun sesuai SAK EMKM. Sesuai SAK EMKM, bahwa setiap UMKM yang sudah memenuhi syarat dan akan mengajukan kredit untuk memperbesar modal usahanya kepada perbankan wajib menyajikan Laporan Keuangan dalam SAK EMKM, maka disusunlah Laporan Keuangan pada Distributor Molreng Jember. Penyusunan laporan keuangan sesuai dengan SAK EMKM yang terdiri dari Laporan Posisi Keuangan, Laporan Laba rugi dan Catatan Atas Laporan Keuangan. Laporan posisi keuangan yang mencerminkan keadaan usaha sebenarnya sehingga pemilik dapat mengambil keputusan keuangan yang tepat. Laporan Laba Rugi yang merupakan evaluasi kinerja usaha yang membuat pemilik mengetahui bagaimana kinerjanya dalam kurun satu periode. Catatan Atas Laporan Keuangan mengungkapkan penelasan lebih lanjut mengenai akun - akun yang pada laporan laba rugi dan laporan posisi keuangan (neraca). Rekontruksi laporan keuangan pada Distributor Molreng Jember dapat mempermudah bagi pemilik untuk dapat mengetahui bagaimana kondisi sebenarnya dari usaha sehingga dapat menentukan harga jual untuk tahun berikutnya.

\section{DAFTAR PUSTAKA}

Undang-Undang Republik Indonesia No. 20 Tahun 2008. Usaha Mikro Kecil dan Menengah. Jakarta: Departemen Keuangan Republik Indonesia.

Ikatan Akuntan Indonesia. Standar Akuntansi Keuangan Entitas Mikro, Kecil, dan Menengah. 2016. Jakarta: Ikatan Akuntan Indonesia.

Hery. 2013. Perusahaan Jasa dan Dagang. Bandung: CV Alfabeta.

Kristanto, E. 2011. Penerapan Standar Akuntansi Keuangan untuk entitas tanpa akuntanbilitas publik (SAK ETAP) pada UMKM Pengrajin Rotan di Desa 
Trangsan Kecamatan Gatak Kabupaten Sukoharjo, Fakultas Keguruan dan Ilmu Pengetahuan, Universitas Sebelas Maret, Surakarta.

Moleong, L. J. 2017. Metodologi Penelitian Kualitatif. Bandung: PT Remaja Rosdakarya.

Pandiagaan, R. 2014. Buku Pintar Akuntansi dan Pengendalina Usaha. Yogyakarta: Laksan.

Rudiantoro, R., dan S. V. Siregar. 2012. Kualitas Laporan Keuangan UMKM Serta Prospek Implementasi SAK ETAP. Jurnal Akuntansi dan Keuangan Indonesia 9 (1):1-21.

Sudaryanto, Ragimun, dan R. R. Wijayanti. 2012. Strategi Pemberdayaan UMKM Menghadapi Pasar Bebas Asean.

Sugiyono. 2010. Metode Penelitian Kuantitatif dan R\&D. Bandung: CV Alfabeta.

Suryana. 2010. Metodologi Penelitian Model Praktis Penelitian Kuantitatif dan Kualitatif. Bahan Ajar Perkuliahan. Bandung: Universitas Pendidikan Indonesia.

Warsono, S. 2010. Akuntansi UMKM Ternyata Mudah Dipahami dan Dipraktikkan. Yogyakarta: Asgard Chapter. 